\title{
Piotr Skowronek
}

\section{Trzy interpretacje kanonu 1083 §2, $1^{\circ}$ KPK}

Prawo Kanoniczne : kwartalnik prawno-historyczny 22/3-4, 157-177

1979

Artykuł został zdigitalizowany i opracowany do udostępnienia w internecie przez Muzeum Historii Polski w ramach prac podejmowanych na rzecz zapewnienia otwartego, powszechnego i trwałego dostępu do polskiego dorobku naukowego i kulturalnego. Artykuł jest umieszczony w kolekcji cyfrowej bazhum.muzhp.pl, gromadzącej zawartość polskich czasopism humanistycznych i społecznych.

Tekst jest udostępniony do wykorzystania w ramach dozwolonego użytku. 


\section{FSS. PIOTR SKOWRONEK}

\section{TRZY INTERPRETACJE KANONU $1083 \S 2,1^{\circ}$ KPK}

Wstęp. 1. Błąd faktyczny obiektywnie i subiektywnie istotny w zgoyzie małżeńskiej. 2. Interpretacja najściślejsza. a) kard. P. Gasparri b) F. Cappello. 3. Interpretacja ścisla. a) św. Tomasza z Akwinu b) Tomasza Sancheza c) Alfonsa Liguori. 4. Interpretacja szeroka. a) wyroki rotalne b) wyroki oficjalatów francuskich. Zakończenie.

\section{Wstęp}

Zgodnie $\mathrm{z}$ kanonem $1081 \S 1 \mathrm{KPK}$ wiadomo, że istotnym elementem zawarcia małżeństwa jest zgoda małżeńska między osobami prawnie zdolnymi. Zgoda ta jednak nie stanowi tylko pewnego stwierdzenia, ale polega na wzajemnym i dobrowolnym daniu i przyjęciu konkretnych uprawnień i zobowiązań. Narzeczeni wyrażają wzajemną i wiążącą zgodę na związek małżeński, który zawierają z własnej inicjatywy, ale sami go nie wymyślili 1. Co do natury swojej związek ten określony jest przez prawo Boże naturalne i pozytywne ${ }^{2}$, a przez Chrystusa uświęcony i podniesiony do godności sakramentu ${ }^{3}$.

Przedmiot zgody małżeńskiej według tradycyjnego sformułowania zostal ujęty jako przekazanie i otrzymywanie dozgonnego i wylącznego prawa do własnej osoby odnoszące się do czynności zdatnych z siebie do wydania potomstwa. W świetle ujęcia Soboru Watykańskiego II 4 owo „ius in corpus" zostało pelniej i dogłębniej naświetlone. W ujęciu soborowym uprawnienie to dotyczy zjednoczenia się w społeczności małeżńskiej rozumianego jako ,ius ad communionem". obejmuje ono caly kompleks spraw i obowiązlów właściwych max́żeństwu, a określonym obecnie jako „wspólnota życia” — „consortium vitae", polegająca na wzajemnym oddawaniu się i dopelnianiu się stron. Można by zaryzykować twierdzenie, że „wspólnota życia” jest̂ pelniejszym, wszechstronniej naświetlonym odpowiednikiem wszystkich trzech dóbr: jedności, nierozerwalności i potomstwa ${ }^{5}$.

Niezależnie od tradycyjnego lub soborowego ujęcia przedmiotu zgo-

1 Żurowski Marian, Kanoniczne prawo matżeńskie okresu posoborowego, Katowice 1976, s. 232.

${ }^{2}$ Pi us XI, Casti connubii, encykl. z 1930 r. w: Breviarium Fidei, Poznań 1964, roz. VII, nr 609, s. 607.

3 E.f. 5, 22-32; Mt. 19, 3-12; Mk 10, 1-12; Ek. 16, 18.

4 Konstytucja pastoralna o Kościele Gaudium et spes $\mathrm{nr} 48 \mathrm{n}$.

z Z u r ow s k i Marian, dz. c. s. 234. 
dy małżeńskiej należy stwierdzić, że zgoda malżeńska jest aktem wolr. sianowiącym następstwo uprzedniego poznania. Stąd nieważność umowy małżenskiej może być spowodowana zarówno brakiem samej zgody, jak i różnymi okolicznościami, które wypływając na rozum i wolż. ngraniczają tę zgodę $w$ sposób istotny czy to mocą prawa naturalnego, czy też mocą pozytywnego prawa kościelnego do tego stopnia, że staje się ona wadliwa. Logicznie przeto wady zgody małżeńskiej z prawa naturalnego będą pochodzily również z braku używania rozumu lub braku odpowiedniego uświadomienia istotnych celów i właściwości małżeństwa, $z$ błędu faktycznie i subiektywnie istotnego oraz z pozornej zgody. $\mathrm{Z}$ pozytywnego prawa kościelnego będą pochodzily natomiast takie wady zgody małżeńskiej jak błąd co do przymiotu osoby r.p. stanu niewolniczego osoby, przymus i bojaźń w stopniu określonym w KPK.

Pomijając inne wady zgody małżeńskiej przedmiotem zainteresowania niniejszego artykułu jest bład faktyczny subiektywnie istotny w zgodzie małżeńskiej, albo mówiąc jaśniej przedmiotem poniżej przedstawionych rozważań jest błąd co do przymiotu osoby sprowadzający się do błędu co do osoby według trzech różnych interpretacji, czyli krótko w artykule tym chodzi o ewolucję interpretacji kanonu $1083 \S 2.1^{\circ} \mathrm{KPK}$. Celem jaśniejszego ujęcia naszego zagadnienia wprowadzone zostało i w kilku zdaniach omówione rozróżnienie między błędem faktycznym obiektywnie istotnym a błędem faktycznie subiektywnie istotnym.

\section{Błąd faktyczny obiektywnie i subiektywnie istotny w zgodzie malżeńskiej}

Pomijając inne zagadnienia błędu faktycznego należy tutaj podkreslić bardzo ważny błąd $w$ zgodzie małżeńskiej tzw. błąd faktyczny co do osoby.

Zgoda małżeńska między określonym mężczyzną a określoną kobietą zbudowana jest $z$ dwóch podmiotowych aktów woli, a każdy $z$ nich ra za przedmiot osobę drugiego kontrahenta. Osoba drugiego kontrahenta może być jednak zidentyfikowana albo obiektywnie na bazie identyczności fizycznej, albo na bazie jakiegoś jednego przymiotu. który zastępuje w umyśle pierwszego nupturienta indywiduum fizyczre. W zakresie prawnej formacji zgody małżeńskiej osoba ludzka ma. podwójne znaczenie: $z$ jednej strony osoba ludzka swoja wola daje życie związkowi małżeńskiemu - a $z$ drugiej strony sam kontrahent jest przedmiotem woli drugiego współpartnera ${ }^{6}$.

W przypadku więc zawierania małżeństwa różnica identyfikacji oso-

- O. Fumagalli Caruli i, L'error redundans nel quadro della. matrimonio canonico w: Ephemerides Iuris Canonici, annus 29 (1973) s. $238-239$. 
by kontrahenta polega jedynie na sposobach identyfikowania. Przy pierwszym $z$ wymienionych sposobów identyfikacji może zrodzić się kłąd faktycznie obiektywnie istotny, przy drugim zaś błąd faktyczny subiekty wie istotny. Zdaniem de Nauroisa KPK w kan. 1083 1 i 2. $1^{\circ}$ wskazuje na tę samą przyczynę nieważności małżeństwa $z$ powodu błędu co do osoby ?. Bląd faktyczny istotny przy zwieraniu małżeństwa może więc dotyczyć albo samej osoby albo jej przy miotu ${ }^{8}$.

Do ważności małżeństwa wymagana jest więc $w$ sposób istotny wzajemna zgoda małżeńska mężczyzny i kobiety, którzy wzajemnie wystarczająco się zidentyfikowali ${ }^{9}$. Obiektywnie istotnym elementem przedmiotu zgody malżeńskiej jest zatem osoba partnera. KPK w kanonie 104 stwierdza, że błąd unieważnia czynność prawną, jeżeli odnosi się do tego, co stanowi o jej istocie.

W konsekwencji tych stwierdzeń należy zauważyć, że jeżeli $\mathrm{w}$ chwili zawierania małżeństwa jedna ze stron nie jest osobą, za którą się podaje, nie może być mowy o ważnym małżenstwie, poniewaz intencja drugiego nupturienta skierowana jest na inną osobe, czyli do innego podmiotu. Klasycznym tego przykladem często cytowanym przez kanonistów jest biblijne małżeństwo Jakuba z Lią zamiast $z$ Rachelą, o którą prosil ${ }^{10}$. Istnieje tutaj bowiem rozbieżność między stanem rzeczywistym a intencją działającego ${ }^{11}$. Dla zaistnienia tego rodzaju błędu muszą zachodzić równocześnie trzy następujące warunki:

a) ktoś pragnie zawrzeć małżeństwo $z$ osobą ściśle określoną

b) inna osoba przedstawia się za tę osobę ściśle określoną

c) oszukany mniemając, że jest to ta ściśle określona osoba, zawiera z. nią małżeństwo.

Wpływ tego błędu na nieważność umowy małżeńskiej uregulowany jest w Kodeksie Prawa Kanonicznego w kanonie 1083. W paragrafie 1. tego kanonu ustalona jest zasada, że błąd faktyczny obiektywnie istotny, a więc odnoszacy się do samej osoby, sprawia, że małżeństwo jest nieważne.

Poza błędem faktycznie istotnym obiektywnie, czyli poza blędem co do samej osoby może zaistnieć przy zawieraniu małżenstwa bląd co do przymiotów osoby. Błąd co do przymiotów partnera do małźństwa może być wynikiem podstępu drugiej strony lub osób postronnych, albo też może pochodzić $z$ wlasnej winy, naiwności, braku daru

${ }^{7}$ L. de $\mathrm{Na}$ a rois, La nullité du mariage sur la personne en droit canonique, w: L'Annèe Canonique 17(1973) s. 668.

${ }^{8} \mathrm{Cappello}$ F. Tractatus canonico-moralis de sacramentis, vol. V, De matrimonio, Romae 1961, nr 585.

9 Wernz-Vidal, Ius canonicum ad codicis normam exactam, $\mathrm{T}$. $\mathrm{V}$, Ius matrimoniale, Romae 1925, s. 557, nr 467.

${ }_{10} \mathrm{Rdz} .29,28$

11 Z u r o w s ki M. dz. c. s. 255 
spostrzegania itp. We wszystkich podobnych przypadkach mamy do czynienia ze zwyklym błędem co do przymiotu osoby, który nie un i eważnia związku małżeńskiego. Jeżeli więc błąd dotyczy przymiotów partnera jak np. urodzenia, majątku, wykształcenia, stanowiska spolecznego, urody, trzeźwości, pracowitości, niepłodności, wieku, itd, to w myśl kanonu $1083 \S 2$, błąd taki nie unieważnia przymierza małżeńskiego. Wszelki zatem bląd nieistotny, czyli nie odnoszący się do samej osoby, lecz tylko do drugorzędnej cechy, czyli przymiotu nupturienta nie wpływa na ważność zgođy małżéskiej, nawet gdyby się stał motywem zawarcia małżeństwa. Zgoda małżeń.ska $z$ natury rzeczy $w$ tych przypadkach posiada wszystkie istotne elementy, niezbędne do zawarcia małżeństwa. Przymioty natomiast, o których w tej chwili jest mowa, są cechami drugorzędnymi, które rie mają wplywu na samą istotę aktu, a tym samym i na ważność tego aktu. Faktyczne uzależnienie zgody małżeńskiej od istnienia lub rieistnienia konkretnego przymiotu następuje w akcie warunkowym ${ }^{12}$.

Tę właśnie interpretację kanonu $1083 \S 2$ każe nam przyjąć słowo "tantum" zawarte w cytowanym kanonie, które wyraźnie wskazuje na to, że prawodawca kościelny uwzględnia tylko dwa taksatywnie przez siebie wyliczone przypadki jako dopuszczalne tytuły nieważności małżeństwa $\mathrm{z}$ powodu blędu co do przymiotu osoby: ${ }^{13}$

$1^{\circ}$ jeżeli błąd co do przymiotu staje się blędem co do osoby;

$2^{\circ}$ jeżeli osoba wolna zawiera malżeństwo z osobą, którą uważa za wolną, podczas gdy jest ona niewolnikiem $\mathrm{w}$ ścisłym znaczeniu ${ }^{14}$.

$\mathrm{W}$ ten sposób prawodawca kościelny ustalając konkretne normy prawre dotyczące blędu w zgodzie małżeńskiej odróżnia przy błędzie co co przymiotów osoby błąd prawny i zwykły od błędu co do przymiotu osoby identyfikującego się $z$ blędem co do osoby i od błędu co do niewolniczego stanu, czyli uwzględnia tylko "error qualitatis redundans in errorem personae" i ,error conditionis servilis".

Pewne określone przymioty mogą dokładnie zindywidualizować osobę i odróżnić ją od wszystkich innych ludzi. Dla przykładu: Tylko jedna $z$ trzech córek dyrektora $X$ może być jego pierworodna córką. Jeżeli by więc ktoś chciał zawrzeć małzeństwo z pierworodną córka owego dyrektora w nadziei otrzymania wielkiego spadku, a na jej miejsce przedstawiono by narzeczonemu drugą lub trzecią córkę dyrektora $X$, wtedy małżeństwo trzeba by uznać za nieważne. Narzeczory bowiem nie chce zawrzeć związku małżeńskiego z podstawioną córką dyrektora $\mathrm{X}$, ale $\mathrm{z}$ kobietą, która jest mu znana tylko z przymiotu, że jest pierworodną córką wymienionego dyrektora. W ten

12 Tamże str. 257

$13 \mathrm{Rybczyk} J$. Podstępne wprowadzenie $w$ blad jako postulowany tytut nieważności w: Roczniki Teolog.-kanoniczne, t. 10(1963) z. 4, s. 125 .

${ }_{14} \mathrm{~B}$ iskupski S., Prawo matzeńskie Kościola rzymsko-katolickiego, Warszawa 1956 , s. $277-278$. 
sposób przymiot „pierworodności” tej kobiety indywidualizuje i odróżnia ją od wszystkich innych ludzi. $\mathrm{Z}$ każdym innym przymiotem indywidualizującym i odróżniającym konkretną osobę od wszystkich ijnnych ludzi sprawa jest identyczna. W przypadku więc podstawienia jakiejkolwiek innej osoby, bład co do przymiotu nupturienta sprowadzi się do błędu co do samej osoby. Tego rodzaju bląd zwykle jest możliwy przy zawieraniu małzeństwa przez pełnomocnika, albo jeżeli jeden z nupturientów określa przymiotem drugiego kontrahenta, który osobiście jest mu zupełnie nieznany ${ }^{15}$.

Przyjęte więc przez KPK, a właściwe już uprzedniej tradycji kanonicznej rozróźnienie między blędem co do przymiotów osoby nie unieważniających $w$ zasadzie małżeństwa a błędem faktycznie slibiektywnie istotnym unieważniającym małżeństwo przyczyniło się do wskazania kryterium indywidualizacji pojęcia osoby $w$ odróżnieniu od pojęcia przymiotu osoby. Rozróżnienie to jest konieczne i ważne, ponieważ błąd co do przymiotów osoby nie zawsze jest kez znaczenia prawnego. Przyjmuje się bowiem, że błąd co do przymiotów osoby powoduje nieważność małżeństwa tyle razy, ile razy błąd ten sprowadza się do błędu co do osoby. Błąd co do przymiotu osoby identyfikujący się $z$ błędem co do osoby był właśnie $w$ przeszłości i jest również dzisiaj przedmiotem analiz kanonicznych ${ }^{16}$.

Wszyscy autorzy przyjmuja - na co zwraca uwage kard. Gasparri 17 - że błąd co do przymiotu osoby sprowadzający się do błędu co do osoby unieważnia zgodę małżeńska, albo krótko - małżeństwo. Autorzy ci jednak nie zgadzają się między sobą $W$ określaniu momentu, kiedy błąd co do przymiotu osoby staje się błędem co do osoby. Zagadnienie to jest bardzo ważne i trudne. Błąd co do przymiotu osoby identyfikujacy się $\mathrm{z}$ blędem co do osoby może być interpretowany na trzy różne sposoby.

\section{In terpretacja najsciśle jssa (tradycy jna)}

Interpretacja, jaką tradycyjna doktryna kanonistyczna stosuje celem wytłumaczenia pojęcia osoby jako przedmiotu poznania partnera do małżeństwa, sprowadza się w sposób bardziej lub mniej oczywisty do pojęcia ,indywidualizacji fizycznej" drugiego kontrahenta ${ }^{18}$.

KPK w kan. $1083 \S 2.1^{\circ}$ przewiduje nieważność małżeństwa w przypadku, gdy błąd dotyczący przymiotu osoby jest równoznaczny z błędem co do samej osoby, czyli dotyczy takiego przymiotu, który cokladnie określa i indywidualizuje osobę.

Przypadek wymieniony $w$ kan. $1083 \S 2,1^{\circ}$ znajduje zastosowanie, gdy w umyśle błądzącego jakiś przymiot indywidualizuje osobę nie-

${ }^{15}$ Linneborn J. - Werner J., Grundriss des Eherechts nach dem Codex Iuris Canonici, Paderborn 1933, s. 308.

${ }_{16} \mathrm{O}$. F u magalli Caruli, dz. c. s. $214-215$

17 Gasparri P., Tractatus canonicus de Matrimonio, editio tertia, vel. IIII, Parissis 1904, s. 16, $\mathrm{nr} 893$.

18 O. Fumaga 11 i Caruli, dz. c. s. $215-216$ 
znaną tak, że wyróżnia ją od wszystkich innych ludzi i na tak wlaśnie zindywidualizowaną przez przymiot osobę ślubujący wyraża zgodę. W pewnych więc okolicznościach przymiot osoby jest tak charakterystyczny, że indywidualizuje samą osobę i wtedy właśnie może zaistnieć błąd co do przymiotu osoby sprowadzający się do blędu co. do osoby. Dzieje się tak dlatego, że błądzący na podstawie tego charakterystycznego przymiotu wyrabia sobie decydujący sąd dla poznania osoby nieznanej i nieobecnej ${ }^{19}$.

Mimo że w tym przypadku błąd dotyczy przymiotu osoby, to jedrak w gruncie rzeczy jest to bląd co do samej osoby, $z$ tą tylko różnicą, że tutaj realizuje się poprzez przymiot osoby a nie w sposób bezpośredni, jak przy blędzie istotnie obiektywnym i chociaż omawiany błąd jest błędem co do przymiotu osoby, to jednak powoduje nieważność małżeństwa $z$ prawa naturalnego podobnie jak przy błędzie co co do samej osoby ${ }^{20}$. Błąd ten utożsamia się więc $z$ błędem faktycznym obiektywnie istotnym i dlatego małżeństwo zawarte $\mathrm{w}$ takich warunkach jest nieważne $\mathrm{z}$ prawa naturalnego zarówno wśród chrześcijan jak i niechrześcijan, bo nie ma w tym wypadku prawdziwej umowy ezyli zgody małżeńskie.j ${ }^{21}$.

\section{a) Interpretacja kard. P. Gasparri}

Jeżeli zgodnie $z$ doktryną tradycyjną, przy hipotezie, że poznanie się przyszłych małżonków poprzez kontakt bezpośredni jest niemożliwe i może się dokonać tylko poprzez dokładne określenie przymiotów partnera, wtedy w myśl tej doktryny odgrywają one wyjątkowo ważną rolę, równoznaczną $z$ kontaktem bezpośrednim, ponieważ $z$ braku kontaktu osobistego przymioty te działają na wolę nupturientów ${ }^{22}$.

Kardynał Piotr Casparri ${ }^{23}$ uważa w tym przypadku, że błąd co do przymiotu osoby sprowadzający się do błędu co do osoby zajdzie wówczas, gdy nupturient chce zawrzeć związek małżeński $z$ osobą określoną i zdeterminowaną przymiotem np. „X" chce zawrzeć kontrakt małżeński ze starszą, nieobecną i nieznaną mu osobiście skądinąd córką "Y", a tymczasem bierze za żonę kobietę, która podaje się za starszą córke „Y”, podczas gdy w rzeczywistości nią nie jest. W tym przypadku zachodzi błąd co do przymiotu osoby, ponieważ "X" jest przekonany, że przedstawiająca się kobieta to starsza córka "Y", podczas gdy jest to zupelnie inna kobieta. Bląd co do przymiotu nupturienta sprowadza się $w$ tym przypadku do błędu co do osoby.

Dla Gasparriego jest rzeczą obojętną, czy osoba ta, w naszym przy-

19 B i s k u p s ki S., dz. c. s. $278-282$

$20 \mathrm{R} \mathrm{y} \mathrm{b} \mathrm{c} \mathrm{z} \mathrm{k} \mathrm{J.,} \mathrm{dz.} \mathrm{c.} \mathrm{s.} 125$

21 We r n z-Vida 1 , dz. c. s. 558 , nr 468

22 O. Fumagalli Caruli, dz. c. s. 216--217

${ }^{23} \mathrm{G}$ a s parri P., dz. c. s. 16 , nr 893 
kładzie starsza córka "Y”, została określona swoim własnym imieniem, czy té̇ innym przymiotem indywidualizującym. Ważnym natomiast dla Gasparriego elementem jest fakt, że osoba była nieobecna i osobiście nieznana nupturientowi.

Jeżeli by jednak osoba podająca się za starszą córkę "Y" była znana osobie "X" $\mathrm{X}$ on byłby przekonany, że osoba ta rzeczywiście jest starszą córką „Y" i z nią zawiera małżeństwo, wtedy nie zachodziłby błąd co do przymiotu współpartnera sprowadzający się do błędu co do osoby, ale błąd zwykly będący wprawdzie przyczyną kontraktu (causam dans), ale nie unieważniający samego kontraktu malżeńskiego.

W przypadku bowiem, gdy jeden $z$ kontrahentów przyjmie fałszywe imię, tytuł itp. a poza tym jest osobą dokładnie i dobrze znaną drugiemu kontrahentowi, wtedy tego rodzaju błąd nie czyni małżeństwa nieważnym, mimo że ludzie między sobą indywidualizują się imionami, tytułami itp. ${ }^{24}$

Krótko więc można stwierdzić, że błąd co do przymiotu nupturienta sprowadzający się do błędu co do osoby tylko wówczas unieważnia związek małżeński, gdy osoba, którą zindywidualizowano przymiotem, jest osobiście nieznana, a inna osoba podaje się za osobe zindywidualizowaną ${ }^{25}$. A zatem $w$ razie podstawienia osoby innej od zindywidualizowanej małżeństwo będzie $z$ całą oczywistością nieważne. Zainteresowany nie myli się bowiem co do natury aktu, ani co do jego cech istotnych, ale błądzi co do konkretnej osoby. W tym przypadku zachodzi błąd faktyczny subiektywnie istotny ${ }^{26}$.

Krótko mówiąc kard. P. Gasparri chce oprzeć swoją interpretację na nauce św. Tomasza $z$ Akwinu i Sancheza, ale wymaga dla nieważności zgody małżeńskiej dodatkowej okoliczności, która nie jest wymagana ani przez św. Tomasza, ani przez Sancheza, a mianowicie, że osoba indywidualizowana przez przymiot jest nieobecna i osobiście nieznana drugiemu kontrahentowi ${ }^{27}$. Istotą tej interpretacji więc jest dopuszczenie jedynego przypadku nieważności małżeństwa wskutek blędu co do osoby ${ }^{28}$.

\section{b) Interpretacja Feliksa Cappello}

Feliks Capello interpretuje kanon $1083 \S 2,1^{\circ} \mathrm{w}$ sposób jeszcze hardziej kategoryczny i rygorystyczny. Uważa on tę normę KPK za niepotrzebną i zbyteczną. Przymiot bowiem, o który tutaj chodzi, w przekonaniu tego autora dotyczy tylko i wyłącznie tożsamości fizycz-

${ }^{24}$ Linneborn J. - W erner J., dz. c. s. $308-309$

25 B is kupski S., dz. c. s. 282

26 ż urowski M., dz. c. s. 225

27 D en is Jacques, Erreur sur la personne et consentement matrimonial w: L'Annèe Canonique, 18(1974) s. 100

${ }_{28}$ L. de $\mathrm{N}$ a u ro is, dz. c. s. 668 
nej osoby, ponieważ poprzez ten przymiot osoba zostaje określona i dzięki temu staje się znana drugiemu nupturientowi. Przymiot ten jednak jest tak właściwy określonej osobie, że charakteryzuje ją w swojej specyfice i odróżnia od wszystkich innych ludzi. Nie chodzi tutaj o przymiot właściwy $w$ sensie filozoficznym Iub prawnym, ale o przymiot w sensie zwykłego nazewnictwá, dzięki któnemu osoba jest znana, wołana i odróżniana od innych ludzi. Dopiero tutaj zdariem F. Cappello może być mowa o blędzie substancjalnym. Błąd ten jednak nie różni się od błędu, o którym mowa jest w § 1 kanonu 1083 KPK. Dlatego też wspomniany autor uważa, ̇̇e bardziej właściwe nie mówić oddzielnie o tym błędzie, dzięki czemu uniknie się błędnych interpretacji ${ }^{29}$.

Krótko więc należy stwierdzić, że błąd co do przymiotu osoby identyfikujący się $z$ biędem co do osoby zostaje zredukowany $w$ tej interpretacji wyłącznie do błędu imienia, ponieważ przymiot indywidualizujący współpartnera jest właściwy tylko zindywidualizowanej osobie i dzięki niemu drugi kontrahent poznaje i odróżnia osobę zindywidualizowaną od innych osób, co w ostateczności sprowadza się do imienia tej osoby. Dlatego też nieważność małżeństwa wypływająca $z$,error redundans" jest tą samą nieważnością co wypływającą z "error personae" 30. Przymiot bowiem w tej interpretacji pojęty jest jako jedyna cecha pozwalająca zindywidualizować i zidentyfikować osobę fizyczną nieobecną i nieznaną. Pozornie chodzi o błąd co do przymiotu, a $\mathrm{w}$ rzeczywistości jest to biad co do osoby ${ }^{31}$.

Interpretacji Cappello pojmującej błąd co do przymiotu nupturienta sprowadzający się do błędu co do osoby, jako błąd sprowadzający się do imienia przyszłego współmałżonka sprzeciwia się Vermeersch-Creusen ${ }^{32}$. Zdaniem Vermeerscha-Creusena osoba może zostać odróżniona od wszystkich innych ludzi i ściśle określona nie tylko foprzez kontakt osobisty̆ albo imieniem, ale również każdym innym przymiotem.

Omawiając $\mathrm{w}$ wyroku $\mathrm{z}$ dnia 21.IV.1970 r. trzy możliwości interpretacji błędu co do przymiotu sprowadzającego się do błędu co do osoby, Canals staje na podobnym jak Vermeersch-Creusen stanowisku uznając, że w interpretacji trađycyjnej, najściślejszej, przyjmuje się przymiot jako jedyną cechę identyfikująca osobe fizyczną skądinąd rieznaną. W aspekcie nazewnictwa więc zachodzi tutaj błąd co do przymiotu nupturienta, podczas gdy $\mathrm{w}$ rzeczywistości jest to bląd co do osoby ${ }^{33}$.

29 Cappello F., Tractatus canonico-moralis de sacramentis, vol. $\mathrm{V}$, De matrimonio, Romae 1961, s. 557, $\mathrm{nr} 586$

${ }_{30}$ O. F u ma g a 11 i Caruli, dz. c. s. 222

31 Den is J, dz. c. s. 97

${ }^{32}$ Vermeersch A. - Creusen J., Epitome Iuris Canonici cum commen tariis, T .II, s. 261 , nr 370

33 Ephemerides Iuris Canonici 26(1970) s. 442-443 


\section{Interpretacja ścisła.}

Poza tradycyjną interpretacją klasyczną spotykamy w wyrokach rotalnych ${ }^{34}$ i u autorów interpretację mniej ścisłą, w której przymiot wspólpartnera do małżeństwa jest przedmiotem bardziej zamierzonym przy zawieraniu małzeństwa aniżeli sama osoba. $W$ tym przypadku przymiot determinuje osobę ${ }^{35}$.

Mężczyzna chce poślubić np. młodą muzyczkę i sądzi, że Maria właśnie jest młodą utalentowaną muzyczką. Intencja nupturienta zmierza $w$ tym przypadku wprost $\dot{i}$ zasadniczo do przymiotu osoby a dopiero na drugim miejscu do osoby. Osobie zaślubiającej $w$ tym przypadku w pierwszym rzędzie chodzi o przymiot, o osobę zaś tylko o tyle, o ile jest ona nosicielem tego właśnie przymiotu. W tej sytuacji więc ,error redundans in errorem personae" będzie dotyczył nie konkretnej osoby, ale osoby abstrakcyjnej posiadającej ten właśnie przymiot ${ }^{36}$.

\section{a) Interpretacja św. Tomasza i jego zwolennikków}

Sw. Tomasz - jak zauważa Möhler - wyraźnie rozróżnia między „personam directe intentam" i "qualitatem directe intentam". Z kolei św. Tomasz uważa małżeństwo za nieważne, jeżeli jeden z nupturientów nie posiada przymiotu wspólnego kilku osobom, który jeđnak jest pożądany wprost $\mathrm{i}$ sam $\mathrm{w}$ sobie przez drugiego nupturienta $\mathrm{w}$ ten sposób, że przewyższa samą osobę, która ten przymiot powinna posiadać, a w rzeczywistości go nie posiada. Tego rodzaju błąd co do przymiotu nupturienta sprowadza się do błędu co do samej osoby. Tutaj również zachodzi rzeczywiste podstawienie osoby $\mathrm{z}$ powodu błędu co do indentyczności fizycznej współpartnera ${ }^{37}$. To ostatnie stwierdzenie ilustruje św. Tomasz konkretnym przykładem. Jeżeli kobieta wprost zamierza' poślubić syna jakiegoś króla, a podstawia się jej osobę inną, której brak jest przymiotu królewskiego, wtedy zachodzi błąd co cio osoby i w konsekwencji małżeństwo jest nieważne ${ }^{38}$.

Podobne stanowisko zajmuje również Dominik Szkot, który stwierdza, że trudno jest ustalić, kiedy bląd co do pochodzenia szlacheckiego lub co do bogactwa, które to błędy same $w$ sobie nie powoduja nieważności małżeństwa, sprowadzają się do błędu co do osoby. Ma to miejsce - jego zdaniem -- kiedy zgoda na malżeństwo nie jest

\footnotetext{
${ }^{84}$ Tamże, s. $442-445$

35 Z u r ow s k i M., dz. c. str. 256

36 Den is J., dz. c. s. 97

${ }^{37}$ Möhler, De errore in qualitate communi ad nuptias quaesita, Apollinaris 34(1961) s. $376-377$

${ }^{38}$ Mostaza A., De ,errore redundante" in doctrina et iurisprudentia canonicis, w: Periorica de re morali, canonica, liturgica, vol. 63 . fasc. $2-3$, s. $388-389$
} 
skierowana wprost na konkretną osobę, lecz odnosi się do niej o tyle tylko, o ile jest pochodzenia szlacheckiego lub bogata, czyli jest rosicielem konkretnych przymiotów ${ }^{39}$.

A. Mostaza zauważa jednak, że Szkot dodaje tutaj, że jeżeli kobieta zamierza poślubić tylko i wyłącznie syna królewskiego lub tylko i wyłącznie człowieka bogatego, a partner nie będzie posiadał pożądanego przymiotu, wtedy małżeństwo będzie nieważne $z$ uwagi na hłąd co do osoby. Jasna jest tutaj według Szkota ,intentio directa” w stosunku do partnera $\mathrm{w}$ podmiocie, który mniema, że partner posiada pożądany przymiot, który zamierza osiągnąć przez małżeństwo ${ }^{40}$.

L. de Naurois podobnie jak Mostaza twierdzi, że Szkot, św. Alfons I:iguori i inni autorzy $w$ ten sam sposób jak św. Tomasz pojmowali błąd co do przymiotu nupturienta sprowadzający się do błędu co co osoby. W ich przekonaniu przymiot był pożąany głównie i przede wszystkim, a osoba jedynie z tytułu posiadanego przymiotu. Jeżeli więc ktoś chce poślubić Marię, o której sądzi, że jest szlachcianką, to małżeństwo będzie ważne nawet $w$ przypadku gdy po zawarciu małżeństwa okaże się, że Maria nie jest szlachcianką. Natomiast, gdy ktoś chce poślubić szlachciankę i poślubi Marię sądząc, że nią właśnie jest, wówczas gdyby okazało się, że Maria nie jest szlachcianką, małżeństwo byłoby nieważne ${ }^{41}$.

Osoby zawierające związek małżeński stanowią zarazem podmiot i przedmiot życia małżeńskiego ${ }^{42}$. Pewne przymioty u wspólmałżonka są tak istotne dla wspólnego życia, że nabierają one dla drugiego partnera znacznie większego znaczenia aniżeli tożsamość fizyczna. Stąd obecność lub brak tych przymiotów sprawia, że osoba staje podmioten i przedmiotem różnym od tego, jakim wydawała się być w chwili zawierania małżeństwa. Różnica wypływająca $z$ ich istnienia lub nieistnienia jest substancjalna, zwłaszcza, jeżeli rozważy się, że powstanie tej glębokiej wspólnoty życia i milości zbudowane jest na przyrnierzu małżonków, czyli na ich osobistej i nieodwołalnej zgodzie ${ }^{43}$. Problem jednak polega na tym, czy przymiot należy pojmować $w$ sensie interpretacji tradycyjnej, jako "qualitas individua", czy téz przedmiotem tego błędu, o którym mowa, może być przedmiot wspólry kilku osobom.

${ }^{39}$ In IV Sent. d. $\bullet$ 0, q. 1. a. 1, ed, Salmaticae 1560, n. 180

to M o s t a z a A., dz. c. s. 389

41 L. de $\mathrm{N}$ a urois, dz. c. s. 669

${ }^{42}$ Gasparri P., Tractatus canonicus de matrimonio, Paryż 1904, vel. I, s. 4

43 De $n$ is J., dz. c. s. 111 


\section{b) Interpretacja Sancheza}

W przypadku, gdy przymiot jest wspólny kilku osobom, Sanchez nie przyjmuje możliwości błędu co do przymiotu nupturienta identyfikującego się z błędem co do osoby. Uważa on bowiem przymiot za srodek identyfikacji fizycznej. Obojętnym natomiast dla Sancheza jest fakt, czy osoba określona jest imieniem własnym, czy też przy pomocy innych określających ją przymiotów ${ }^{44}$. W nauce swojej o błędzie co do przymiotu partnera sprowadzającego się do błędu co do csoby Sanchez powołuje się na św. Tomasza.

Szczegółowo swoją nauke na ten temat Sanchez ujmuje w dwie reguly, które mają być - według niego - pozytywnym i negatywnym ujęciem tej samej zasady. W pierwszej $z$ nich Sanchez stwierdza, że jakikolwiek przymiot, co do którego nupturient jest w blędzie i który nie określa ani nie indywidualizuje pierwszego nupturienta, nie unieważnia małżeństwa. Dopiero jeśli błąd dotyczy przymiotu, który indywidualizuje osobę, młażeństwo zawarte w wyniku powstania tego błłędu jest nieważne, ponieważ tego rodzaju błąd dotyczący przymiotu indywidualizujacego osobe staje się blędem co do samej osoby ${ }^{45}$. W myśl tej teorii przymiot współpartnera wtedy tylko jest indywidualizujący, określający i odróżniający osobę od wszystkich innych ludzi, jeżeli wola nupturienta skierowana jest na ściśle określony przymiot w ten sposób, że brak tego przymiotu powođuje, iż osoba określona iym przymiotem staje się zupełnie inną osobą. Wola bowiem na małżeństwo w pierwszym rzędzie skierowana jest na przymiot, a osoba posiadająca ten określony przymiot schodzi na plan drugi i pojmoWana jest tylko jako "nosiciel" tego określonego przymiotu. Jeżeli więc przymiot ten charakteryzuje i określa bardzo dokładnie samą osobe, wtedy błąd co do przymiotu nupturienta sprowadza się do błędu co do osoby 46; nie indywidualizuje jednak osoby wtedy na przykład, gdy młoda dziewczyna ma ogólny zamiar zawarcia maŕżeństwa $z$ urzędnikiem, oficerem, fabrykantem, muzykiem, naukowcem itp., ponieważ przymiot indywidualizujący osobę- w myśl tej teorii - musi być przymiotem jednej jedynej osoby.

Aby znaleźć środek pozwalający odróżnić błąd co do przymiotu partnera sprowadzający się do blędu co do osoby od błędu zwykłego co do przymiotu Sanchez zakłada, że osoby zamierzające zawrzeć malżeństwo muszą być sobie znane nie osobiście, ale tylko poprzez przymiot indywidualizujący ${ }^{47}$. A Knecht uważa jednak, że ten wymóg San-

\footnotetext{
${ }^{44}$ Sanchez Th., De sancti matrimonii sacramento disputationes, I.ugduni 1625 , lib. VII, disp. XVII, nr 27.

45 Tamże, lib. VII, disp. XVIII, nr 26 i 27

46 Knecht August, Handbuch des katholischen Eherechts auf Grund des Codex Iuris Canonici und unter Beriicksichtigung des bür. geischen Eherechts... Freiburg 1928, s. 556

${ }_{47}$ S a n chez, dz. c. lib. VII, disp. XVII, nr 38
} 
cheza nie może być traktowany jako warunek ,sine qua non" błędu co do przymiotu osoby identyfikującego się z blędem co do nupturienta, ponieważ tego rodzaju błąd może zaistnieć również wówczas, gdy partnerzy do małżeństwa są sobie znani osobiście. W takim jednak przypadku osoba kwestionująca ważność swojego małżeństwa w oparciu o błąd co do przymiotu partnera sprowadzający się do błędu co do osoby musi udowodnić, że rzeczywiście wola jej $w$ pierwszym rzędzie i bezpośrednio kierowała się na przymiot i taką pozostała ${ }^{48}$.

Krótko więc można powiedzieć, że cała nauka Sancheza dotycząca błędu co do samej osoby ma swoje źródło w błęđnej interpretacji jednego pasusu Tomaszowego, ukazującego pớwójny sposób indywidualizacji osoby ${ }^{49}$. Pierwszy sposób indywidualizacji osoby dokonuje się wedlug św. Tomasza $w$ prostym odniesieniu fizycznym „visu ac conversatione". Nie jest to jednak jedyny tylko sposób indywidualizacji osoby; obok niego św. Tomasz ukazuje drugi sposób dokonujący się przy pomocy jakiegokolwiek przymiotu lub znaku, byleby tylko determinował osobe. Jeżeli bowiem $w$ tym drugim sposobie identyfikacji osoby, przymiot lub znak jest zbyt ogólny i niejasny, wtedy trzeba mówić o błędzie co do przymiotów osoby, który jednak nie unieważnia związku małżeńskiego ${ }^{50}$.

\section{c) Interpretacja św. Alfonsa Liguori}

Do drugiego sposobu indywidualizacji osoby nawiązuje również trze-cia regula św. Alfonsa Liguori ${ }^{51}$. W myśl tej reguly błąd co do przymiotu osoby sprowadzający się do błędu co do osoby zachodzî wówczas, gdy zgoda na małżeństwo kieruje się „directe et principaliter in qualitatem, et minus principaliter in personam", co zachodzi gdy na przykład nupturient stwierdza, że chce poślubić muzyczkę i sądzi, że Maria nią wlaśnie jest.

Z tej krótkiej analizy i zestawienia teorii św. Tomasza z Akwinu, Tomasza Sankeza i św. Alfonsa Liguori wynika, że Sanchez i zwolennicy jego tezy przyjmują za przedmiot błędu co do przymiotu współmał̇żonka sprowadzającego się do blędu co do osoby tylko i wyłącznie przymiot indywidualizujący, podezas gdy św. Alfons Liguori i zwolennicy jego tezy przyjmują za przedmiot tego błędu również przymiot wspólny wielu osobom $\mathbf{5 2}$.

Za pośrednictwem tej ostatniej konstrukcji św. Alfonsa Liguoriego caziałanie tego rodzaju błędu usiłuje się rozciągnąc na inne przymio-

\footnotetext{
$48 \mathrm{Kn}$ e c h t A., dz. c. s. $556-557$

49 Summa theologica, Supplementum Partis Tertiae, q. 51, art. 2 ad 5

50 O. Fu m a g a 11 i C., dz. c. s. $217-218$

51 L i g u o r i Alphons, Theologia moralis, Graz 1954, T. IV, L. VI., tract. VI, cap. III, nr 1016, P. 179

${ }^{52}$ O. Fum a ga 11 i C., dz. c. s. $228-229$
} 
ty, nie ograniczając unieważniającego działania tego rodzaju błędu tylko do przymiotu indywidualizującego, co ostatecznie sprowadza się do błędu co do identyczności osoby, polegającego na podstawieniu osób. Tego rodzaju przekonanie o ograniczającej skuteczności nieważności małżeństwa $\mathrm{z}$ powodu ,erroris redundantis" tylko do przymiotu indywidualizującego, usilowano zastąpić innym przekonaniem rozciąając skuteczność tego błędu na przymioty o naturze ogólnej a nie koniecznie indywidualizującej. W ten sposób, $z$ chwilą gdy zabrakło tego charakterystycznego przymiotu natury nawet ogólnej, wtedy osoba współmałżonka, z którą przymiot ten wiązał drugi nupturient, nie jest już tą samą osobą. Tego rodzaju błąd, według św. Alfonsa zachodzi wtedy, gdy intencja nupturienta „principaliter" jest zwrócona na konkretny przymiot, a wtórnie dopiero na osobę jako na nosiciela tego przymiotu. Ta trzecia reguła św. Alfonsa Liguoriego - jak zauważa Hertmut Zapp ${ }^{53}$ - przez większość kanonistów nie została uznana.

Różnica między tezą Sancheza a tezą św. Alfonsa Liguoriego mieści się więc w krańcowo różnym zakresie pojmowania przymiotu $w$ błędzie co do przymiotu partnera identyfikującym się z błędem co do osoby. Koncepcję Sancheza można określić jako zacieśniająca, ponieważ pojmuje przymiot jako srodek fizycznej identyfikacji osoby. Przymiot w koncepcji Sancheza spełnia tę samą role co wzajemne bezpośrednie poznanie się nupturientów to znaczy rolę fizycznej identyfikacji osoby. Koncepcję św. Alfonsa Liguori natomiast można uznać za rozszerzoną, ponieważ przymiot pojmuje w sensie relatywnie ogólnym nie zakładając jednocześnie braku poznania osobistego ,visu ac conversatione" nupturientów.

Różnica między tymi dwoma tezami doktrynalnymi polega jednak nie tylko na zbyt ciasnym lub zbyt szerokim pojmowaniu przymiotu, aje również na różności założeń i przesłanek. Niewątpliwie konsekwencje różnego pojmowania przymiotu sa bardzo istotne przy interpretacji i aplikacji praktycznej kanonu 1083, ale nie mniej ważna jest różnorodność założeń i przesłanek wplywajaca na te konsekwencje. Różnorodność założeń i przesłanek prowadzi ostatecznie do wskazania na współdziałanie między rozumem a wolą. Interakcję między rozumem a wolą trzeba mieć na uwadze, ilekroć bada się zgodę małżeńską. $Z$ punktu widzenia tej interakcji powyższe doktryny nie ukazują się jako przeciwstawne, ponieważ obydwie stosują kryterium obiektywne wiążąc wartość prawną zgody małżeńskiej ze stosunkiem intelekt-wola i stąd jedna $z$ nich posiada za przedmiot identyczrość moralną a druga identyczność fizyczną, z czego ostatecznie wy-

$53 \mathrm{Zapp}$ Hartmut, Der Irrtum im kanonischen Eherecht; Zum Entwurf der Kodexkommission; w: Östrreichisches Archiv für Kirchenrecht, z. $2-3(1973)$ s. $224-225$ 
nika identyfikacja pośrednia lub bezpośrednia ${ }^{54}$. W obu jednak tezach zawsze będzie chodziło o przymiot „per se” czyli obiektywnie fundamentalny i idywidualizujący 55 .

$\mathrm{Z}$ przeprowadzonej analizy wynika więc jasno, że identyczność osoby $\mathrm{w}$ ujęciu prawa kanonicznego nie może być zredukowana tylko do samego pojęcia identyczności czysto fizycznej, co zachodzi w przypadku „error personae". Identyczność osoby nie powinna być więc rozważana tylko obiektywnie w oparciu o kryterium identyczności fizycznej ale powinna być oceniana na podstawie kryterium subiektywnego od strony wartościowania nupturienta błądzącego. W duszy nupturienta bowiem przymioty stanowiące szczegółowy aspekt przyszlego współmałżonka mogą okazać sie ważniejsze od indywiduum fizycźnego $i$ to do tego stopnia, że rozważanie tego lub innego przymiotu cielesnego, intelektualnego czy duchowego całkowicie zastępuje rozważanie identyczności fizycznej przyszłego współmałżonka. $W$ ten sposób do pojęcia identyczności fizycznej zostaje dołączone inne pojęcie identyczności wiążące się $z$ bardziej szerokim pojmowaniem osoby na bazie kryterium podmiotego, a nie obiektywnego ${ }^{50}$.

\section{Interpretacja szeroka}

Wyżej przedstawiona argumentacja O. Fumagalli posiada wartość również dla interpretacji szerokiej błędu co do przymiotu nupturienta sprowadzającego się do błędu co do osoby.

Interpretacja ścisła błędu co do przymiotu partnera sprowadzającego się do błędu co do osoby pochodzi z okresu przedtrydenckiego, kiedy to małżeństwo zawierane było bez formy kanonicznej i na mocy postanowienia rodziców, a podstawe zawarcia małżeństwa stanowiły interesy natury politycznej lub finansowej, kiedy zawieranie małżeństw za pośrednictwem pełnomocników nie bylo niczym nadzwyczajnym i kiedy ostatecznie panowaly zupelnie inne stosunki spoleczne. Wszystkie te okoliczności uległy zupełnej zmianie, a normy prawne, dzisiaj anachroniczne, a nawet niesprawiedliwe, pozostaly niezmienione ${ }^{57}$. Dlatego też warto teraz zająć się nie podstawieniem fizycznym usoby, o którym była mowa w dwóch poprzednich interpretacjach, ale podstawieniem moralnym, kiedy to nupturient przedstawia sie przyszłemu współmałżonkowi symulując przymioty, których w rzeczywistości nie posiada, albo też ukrywa dokładnie okoliczności o znaczeniu istotnym, podstawowym dla przyszlego życia malzeńskiego. W tym przypadku nie można mówié o podstawieniu fizycznym osoby, ale

54 O. F u maga 11 i C., dz. c. s. $229-230$

55 Monet. a P., Errore sulle qualita individuanti ed interpretazione evclutivo, II Dir. eccl. 81(1970) s. 46

56 O. Fumaga 11 i C., ciz. c. s. 237

57 Z a p p H., dz. c. s. $226-227$ 
warto zwrócić uwagę, że $\mathrm{w}$ istocie strona wprowadzona $\mathrm{w}$ bląd nie dała swojej zgody małżeńskiej osobie, którą zamierzała poślubić ${ }^{58}$. Stąd rodzi się pytanie, czy $w$ przypadku blędu co do przymiotu moralnego, prawnego lub socjalnego osoby może zaistnieć „consensus in idem” i czy prawidlowemu pojęciu małżeństwa będzie odpowiadała wola zawarcia takiego małżeństwa? ${ }^{59}$ Musimy tutaj pamiętać o naczelnej zasadzie małżeńskiego prawa kanonicznego, że zgoda mał¿̇eńska nie może być uzupełniona przez żadną władzę ludzką ${ }^{60}$.

a) Interpretacja szeroka $w$ dwóch wyrokach rotalnych

W ostatnich latach przed trybunałami kościelnymi toezyly się dwa ciekawe dla naszych rozważań procesy, które wywołaly szereg komentarzy w literaturze kanonistycznej. Podczas tych procesów rozpatrywane były dwa przypadki małżenstwa, których ważność kwestionowano z tytułu błędu co do przymiotu nupturienta sprowadzającego się do błędu co do osoby. W obydwu przypadkach małżeństwa uznano za nieważne. W obydwu wyrokach można zaobserwować pewna ewolucję błędu co do przymiotu partnera sprowadzającego się do błędu co do osoby ${ }^{61}$.

Jeden z wyroków stwierdza, że Auksiliatrica zawierając małżeństwo 19.X.1965 r. z Ekspedytem padła ofiarą błędu co do przymiotu wspólmałżonka identyfikującego się $z$ błędem co osoby. Auksiliatrica wprawdzie znała Elsspedyta od przeszło 14 miesięcy i była z nim zarecczona, nie wiedziała jednak o jego małżeństwie cywilnym $z$ inną jrobietą i wierzyła, że poślubiła człowieka wolnego. Przyczyną tego był podstęp człowieka symulującego stan wolny $z$ przedstawieniem fałszywego dowodu tożsamości cywilnej. Okoliczność podstępu nie : stwarza tutaj 'trudności, ponieważ nieważność tego małżeństwa wypływa nie tylko $\mathrm{z}$ samego tytułu podstępu, ale przede wszystkim z konsekwencji tego oszustwa, istórą jest błąd co do przymiotu nupturienta identyfikujący się z błędem co do osoby, który ostatecznie spcwodował nieważność małżeństwa. Auksiliatrica zeznała, że gdyby wiedziała o pierwszym małżeństwie Ekspedyta z inną kobietą, nie bylaby się z nim zaręczała, a tym bardziej nie dałaby zgody na to małżeństwo. Z tego stwierdzenia Auksiliatricy, jak i z zeznań świadków, można wyciągnąc wniosek za lub przeciw warunkowi interpretatywnemu, ale nie można zakwestionować istnienia blędu polegającego na falszywym rozumowym poznaniu osoby Ekspedyta, które wówczas dakonało się $w$ Auksiliatrycy. Słowa Auksiliatricy i świadków ujaw.. niają stan rozumowy i wolę nupturientki, która popadła w błąd, a dopiero póżniej odkryła rzeczywisty stan rzeczy.

\footnotetext{
58 Den is J., dz. c. s. $107-108$

${ }^{59} \mathrm{Z}$ a p p H., dz. c. s. 227

60 Por. KPK kan. $1081 \S 1$

01 D en i s., dz. c. s. 95
} 
Bardzo zbliżony $w$ swoich szczegółach do przypadku dopiero co. opisanego jest drugi proces o nieważność małżeństwa, także zakończony stwierdzeniem nieważności małzeństwa $z$ powodu błędu co do, przymiotu osoby.

Obydwie zatem sprawy osądzone $w$ pierwszej instancji przez Sąd Duchowny w Sens, a w drugiej, przez Rotę Rzymska, dotyczą błędu popelnionego przez nupturienta $w$ stosunku do przyszłego współmałżonka w chwili zawierania małżeństwa. Ponens wyroku rotalnego postawif pytanie: czy błąd co do przymiotu osoby sprowadzający się $w$ chwili zawierania małżeństwa do błędu co do osoby niweczy zgodę na malżeństwo i czy kanon $1083 \S 2,1^{\circ}$ nie przytacza dawnego prawodawst-. wa? Nastepnie ponens przedstawił trzy stosowane przez doktryne $i$ jurysprudencję interpretacje odnośnie błędu co do przymiotu nupturien.ta sprowadzającego się do błędu co do osoby zatrzymując interpretacje najszerszą ${ }^{62}$, którą $\mathrm{W}$ myśl wyroku rotalnego ${ }^{03}$ należy stosować: wówezas, kiedy przymiot moralny, prawny lub spoleczny tak jest: wewnętrznie związany z osobą fizyczną, że brak tego przymiotu powo-duje iż osoba ta staje się zupełnie różną osobą fizyczną. Stąd, jeżeli. nupturient sądzi, ze jego przyszly malżonek jest stanu wolnego i $w$ tym przekonaniu zawiera małżeństwo, a po zawarciu małżeństwa okazuje się, iż osoba ta staje się zupełnie różną osobą fizyczną. Stąd, jeżeli wie się, że jego współmałżonek był związany z inną osobą, to małżeństwo będzie nieważne w myśl tej trzeciej wlaśnie interpretacji kanonu 1083 $\S 2,1^{\circ}$, nie dla jakiegoś warunku wewnętrznєgo lub interpretatywnego ale wlaśnie $z$ powodu błędu co do przymiotu nupturienta spowadza.jącego się do błędu co do osoby rozumianej w sposób całościowy i zupelny ${ }^{64}$.

W wyroku tym Canals powołując się na wloskiego prawnika Jemolo wykazuje, że interpretacja ścisła zarówno w prawie cywilnym jak i w kościelnym nie odpowiada dzisiejszej rzeczywistości, że interpretacja przedstawiona przez Sancheza wydaje się być interpretacją zawężonąs. która niedokładnie wyjaśnia doktrynę św. Tomasza z Akwinu. Po drugim Soborze Watykańskim zaszło tyle zmian, że nie można dłużej ograniczać błędu co do przymiotu tylko do tego co dotyczy osoby fizycznej ${ }^{65}$. Jako więc główny argument i uzasadnienie stosowania no-

${ }^{62}$ Tamże, s. $98-99$

63 Ephemerides Iuris Canonici, 25 (1970) s. 442-443: „,... Tertia notio est cum qualitas moralis iuridica socialis tam intime connexa habetur cum persona physica ut, eadem qualitatee deficiente, etiam persona physica prorsus diversa resuitet. Si quis ergo matrimonium contrahat cum persona tantum cięiliter nupta, quam putat quovis vinculo liberam, invalide contrahit iuxta hanc tertiam notionem, non ob alijuam implicitam vel interpretativam conditionem, sed ob errorem qualitatis redundantem in errorem personae magis complete et integre consideratae".

64 Den is J., dz. c. s. 97

05 Dir. Ecel. $81(1970)$ II s. $11-12$ 
wej interpretacji kanonu $1083 \S 2,1^{\circ}$ Rota przytacza zmiany jakie zaszły $w$ życiu współczesnego człowieka ${ }^{66}$.

b) Wyroki dwóch Oficjalatów francuskich.

Dwa oficjalaty we Francji: w Moulin w pierwszej instancji, a w Sens w drugiej instancji również wydały wyrok nieważności małżeństwa w przypadku bardzo zbliżonym do wyżej omówionych. Przyczynami uznania $w$ tych wyrokach błędu co do przymiotu osoby sprowadzającego się do błędu co do osoby były: falszywe dane cywilne, falszywy status rodzinny, dyplom, tytuł, profesja itp. Przyczyny te przedstawiła wprowadzona w błąd powódka. Obrońca węzła małżeńskiego przy Rocie, któremu w trzeciej instancji powierzy sprawę obrońca węzła małżeńskiego z Sens, odmówił apelacji, a tym samym uznał prawdzirrośc wyroku w Moulin $i \mathrm{w}$ Sens. Wyroki w tej sprawie stwierdzaja, że inne czasy powodują również zmiany obyczajów, co sprawia, że bardziej niż przez pochodzenie spoleczne lub rodzinne osoba jest indywidualizowana przez swoją historię osobistą i socjalną. W przypadku rozpatrywanym przez oficjalaty w Moulin i w Sens małżonek został zindywidualizowany i określony substancjalnie poprzez poprzednie małżeństwo cywilne, perwersję seksualną itd. Nic więc dziwnego, że stwierdzono, że w żaden sposób nie może on być czlowiekiem, którego zamierzała poślubić powódka. Zaszedł więc tutaj błąd co do przymiotów indywidualizujących i substancjalnych sprowadzających się do błędu co do osoby. Bez wątpienia należy przyznać, że małżeństwo to nie byłoby zawarte, gdyby prawda o przymiotach pożądanych a $w$ rzeczywistości nie istniejących byla znana przed zawarciem małżeństwa. Nie można w tym przypadku mówić o podstawieniu fizycznym osoby ${ }^{67}$, bo fizycznie jest to ta sama osoba, z którą chciała się złączyć druga strona, jakkolwiek w rzeczywistości nie jest ona tą samą określona pewnymi charakterystycznymi cechami osobą ${ }^{68}$.

Nową interpretacje nauki Prawa Kanonicznego o błędzie co do przymiotu nupturienta sprowadzającym się do błędu co do osoby tylko $W$ bardzo wąskim zakresie można porównać z wyżej przytoczoną interpretacją św. Alfonsa Liguori. Nowa interpretacja ma zakres znacznie szerszy $\mathrm{w}$ porównaniu $\mathrm{z}$ interpretacją św. Alfonsa Liguori. Uznaje ona bowiem nieważność małżeństwa w przypadku błędu co do przymiotu moralnego, prawnego lub socjalnego osoby, jeżeli osoba przez przymiot ten zostala tak określona i scharakteryzowana, że $z$ chwilą braku tego przymiotu przestaje już być tą samą osobą, z którą chciano zawrzeć związek małżeński. Jasną więc staje się rzeczą, że w oparciu - tę interpretację każdy bląd dotyczący jakiegoś ważnego przymiotu

${ }^{66} \mathrm{Z}$ a p p H., dz. c. s. 226

${ }^{67}$ L. de $\mathrm{N}$ a u r o is, dz. c. s. $669-670$

$68 \mathrm{D}$ e n is J., dz. c. s. 101 
osoby czyni małżeństwo nieważnym np. błąd co do zdrowia, zawodu, przeszłości, stanu cywilnego itp. Interpretacja ta zasługuje tym barclziej na uwage, że można ją spotkać nie tylko w literaturze kanonistycznej, ale została ona również uznana za własną Rotę w wyroku z roku $1970{ }^{69}$.

Według nowej interpretacji kanonu $1083 \& 2$ pojęcie osoby musi być rozumiane $\mathrm{w}$ sensie bardziej szerokim od pojęcia osoby stosowarego do niedawna $w$ jurysprudencji $w$ oparciu o doktrynę tradycjoıalną. Obecnie przyjmuje się, że pojęcie osoby ludzkiej stanowi nie tylko sam wymiar materialny, czyli fizyczne indywiduum, ale obejmuje także te jakości i cechy, które charakteryzują w sposób jednoznaczny całą osobowość moralną i cywilną osoby. Jest to zrozumiałe, jeżeli przyjmie się, że człowiek współczesny znajduje się $w$ nieustannym związku ze społecznością, do której należy i dlatego te: winien być rozważany jako rezultat działania czynników socjalnych, historycznych, środowiskowych, które są szczególnie akcentowane przez: nowożytne nauki antropologiczne. Zastosowanie tego stwierdzenia do „error redundans" prowadzi do wniosku, że błąd ten zachodzi wówczas, kiedy jego przedmiotem jest jeden z przymiotów charakteryzujących całkowicie osobowość moralną i społeczną nupturienta, czyli przymiot jest fundamentalny i indywidualizujacy, a brak tego przymiotu sprawia, że życie małżeńskie stałoby się niemożliwe. W przypadku takiego błędu nupturient kieruje swoją wolę ku indywiduum substancjalnie różnemu od tego, jakie chciał poślubić ${ }^{70}$. "Qualitas recundans" pojęta jest tutaj jako atrybut obiektywny, który indywidualizuje osobę nie tyle $w$ jej bycie fizycznym, ile raczej $w$ jej bycie etyczno-społecznym. Można tutaj przytoczyć przykłady błędów różnego rodzaju: błąd co do religii, narodowości, nieświadomości pewnych cech patologicznych lub perwersji, aby wyciągnąć wniosek, że każdy $z$ tych możliwych stanów przeszkadza w zinđywidualizowaniu osoby drugiego nupturienta $w$ jej bycie etyczno-społecznym $w$ stosunku do wymagań życia małżeńskiego ${ }^{71}$.

Przymioty $w$ rozumieniu nowej interpretacji rzeczywiście są środkiem poznania osoby. Koniecznie tutaj trzeba dodać, że prawo mówiąc o błędzie co do przymiotu nupturienta identyfikującym się $z$. błędem co do osoby nie wiąże tego błędu z poznaniem ,individuum" "isu ac conversatione" i dlatego też nie sprowadza „error redundans" do podkategorii "error personae". Tę samą myśl można wyrazić jeszcze inaczej, że prawo nie odsyła tylko do poznania indywiduum dostępnego zmysłom, ale odsyla do poznania bardziej szerokiego, do poznania tego indywiduum jako osoby rozumianej łacznie z tymi cechami,

$69 \mathrm{Z}$ a p p H., dz. c. s. 225

70 O. F u ma g a 11 i C., dz. c. s. $220-221$

${ }^{71} \mathrm{O}$. di Jorio, Errore di. qualita ridendante in errore di persona. nel consenso matrimoniale, w: Dir. Eccl. 81(1970) s. 18 
które osobę tę społecznie odróżniają od innych osób jej podobnych. Należy więc stwierdzić, że „error qualitatis redundans in errorem personae" jest błędem różnym od błędu co do osoby. Dlatego posiada on oddzielną pozycję prawną, mimo że wspólne określenie obydwu zawsze oznacza istnienie błędu co do identyczności osoby $z$ tą tylko różnicą, że błąd co do osoby dotyczy błędnej indywidualizacji fizycznej drugiego nupturienta, natomiast „error redundans” dotyczy błędnej indywidualizacji osobowości społecznej i moralnej drugiej osoby 72 .

\section{Zakończenie}

Z przedłożonej interpretacji błędu co przymiotu osoby identyfikującego się z błędem co do osoby wynika, że współczesna kanonistyka zmierza do rozszerzenia kanonu $1083 \S 2 \mathrm{KPK}$.

Sugeruje ona przyjęcie interpretacji „szerokiej" w kanonie $1083 \S$ ?, $1^{\circ}$. Interpretacja szeroka bowiem przyjmuje możliwość uzyskania dekretu stwierdzającego nieważność małżeństwa w przypadku moralnego, prawnego i socjalnego podstawienia zidentyfikowanej osoby, w przeciwieństwie do interpretacji tradycyjnej $i$ ścislej, które uznawały nieważność małżeństwa wyłącznie w przypadku fizycznego przedstawienia nupturienta zidentyfikowanego przez drugiego współmałżonka tylko za pomocą ściśle określonych przymiotów. Interpretacja szeroka znalazła już swoje zastosowanie i potwierdzenie w kilku wyrokach rotalnych oraz w kilku wyrokach oficjalatów francuskich, które wyżej szerzej zostały omówione. W wyrokach tych zastosowano interpetacje szeroką błędu co do przymiotu nupturienta identyfikującego się $\mathrm{z}$ błędem co do osoby w przypadku błędu co do przymiotu moralnego, prawnego lub socjalnego osoby mającego istotne, substancjalne znacznie dla przyszłego życia małżeńskiego. Krytyka tych wyroków nie dotyczyła interpretacji szerokiej jako takiej, ale dotyczyła słabej motywacji zawartej $w$ tych wyrokach na uzasadnienie racji, dla których zestosowano interpretacje szeroką, przy czym krytycy tacy jak L. de Naurois ${ }^{78} \mathrm{i}$ U. Mosiek ${ }^{74}$ przytoczyli inne racje ich zdaniem bardziej przemawiające za zastosowaniem interpretacji szerokiej kanonu 1083 $\S 2,1^{\circ} \mathrm{KPK}$.

$\mathrm{Z}$ omówionych wyżej wyroków wynika jednak jeszcze coś więcej, a mianowicie, że niejednokrotnie błąd co do przymiotu moralnego, prawnego i socjalnego osoby spowodowany został podstępnym działaniem drugiego współmałżonka, który ukrywał świadomie swój faktyczny stan moralny, prawny lub socjalny do chwili zawarcia małżeństwa.

72 O. Fumag a 11 i C., dz. c. s. $222-223$

${ }^{73} \mathrm{~L}$. de $\mathrm{N}$ a u rois; dz. c. s. 677

${ }^{74}$ Mosiek U., Die neuste Rechtsprechung der $S$. R. Rota w: Osterreichisches Archiv für Kirchenrecht 2-3(1973) s. 186-187 
W tym momencie natrafiamy niejako na drugi kierunek współczesnej kanonistyki zmierzający do rozszerzenia kanonu 1083 \& o błąd co do przymiotu osoby spowodowany podstępnym działaniem drugiego nupturienta. Ten drugi kierunek $w$ dotychczasowym prawie malżeńskim nie był uwzględniony. W życiu jednak dochodzi niejednokrotnie do szczególnie jaskrawej krzywdy strony niewinnej. W konkretnym przypadku chodzi mianowicie o podstepne wprowadzenie drugiej osoby $w$ bląd w materii bardzo ważnej dla przyszłego pożycia małżeńskiego. 'Z rozważań wstępnych niniejszego artykułu wynika, że błąd co do przymiotu osoby tylko wówczas unieważnia związek malżeński, kiedy staje się błędem co do osoby. Jest to norma prawa naturainego ${ }^{75}$. Doświadczenie życiowe jednak narzuca potrzebę wprowadzenia pozytywnej ochrony prawnej dla decyzji o tak doniosiych konsekwencjach, podobnie jak to uczynil prawodawca broniąc swobodnej decyzji nupturientów żądając w tym celu wolności kwalifikowanej. Słusznie chyba postuluje się więc wprowadzenie wady zgody małżeńskiej z tytułu podstępnego wprowadzenia $w$ błąd, unieważniającej zgodę malżeńską. Jodstępne doprowadzenie do zawarcia małzeństwa może bowiem przyszłe pożycie małżeńskie utrudnić, a nawet uczynić bardzo cięż$\lim { }^{76}$.

Ten drugi kierunek rozszerzenia kanonu $1083 \S 2$ o tytuI podstępnego wprowadzenia $w$ błąd podjęty przez wielu współczesnych kanonistów wykracza jednak poza temat podjęty przez autora niniejszego artykulu a ponad to stosunkowo dosyć szeroko był już dyskutowany nawet wśród kanonistów polskich 77. Dlatego też poprzestano $\mathrm{w}$ tym artykule na ukazaniu tylko pierwszego kierunku usilowań rozszerzenia kanonu $1083 \S 2$.

\section{Trois interprètations du canon 1083. 2,1 (D. C.)}

La personne du deuxième contractant fait l'objet indispensable du consentement matrimonial, qui peut être identifièe soit objectivement par son identitè phisique, soit subjectivement par une qualitè quelconque. Le lègialateur ecclesiastique du canon 1083, 2, 1 (C. D. C.) affirme indirectement que l'erreur sur la qualitè de la personne rend le consentement nul seulement lorsqu'elle se ramène à l'erreur sur la seule personne sur l'identitè du deuxième contractant. De là vient notre article: Quelles doivent ètre les conditions pour que l'erre.ur sur la qualitè de la personne se ramène à l'erreur sur l'identitè

75 Z u rowski M., dz. c. s. $260-261$

${ }^{76} \mathrm{R} \mathrm{y} \mathrm{b} \mathrm{c} \mathrm{z} \mathrm{y} \mathrm{k} \mathrm{J.,} \mathrm{dz.} \mathrm{c.} \mathrm{s.} 126$

77 Zobacz: Rybczyk J., dz. c.; Wyszyński M. Z powodu projektu powiększenia nieważności malżeńswta zawartego pod wpiywem błędu w: Roczniki teologiczno-kanoniczne. t. 10(1963) s. 245-262; Z ube r $t$ B. W., Dyskusja nad uznaniem nieważności matżeństwa $z$ tytulu podstepnego wprowadzenia $w$ btad w: Roczniki teologiczno-kanoniczne t. $18(1971)$ z. 5, s. $75-92$. 
de la personne? Il y a trois solutione possibles; la rèponse à notre problème dèpendra de l'intepretation admise. L'auter prèsente brièvement les trois interprètations et leurs reprèsentants principaux.

A - L'interprètation la plus stricte admet que l'erreur sur la qualitè de la personne rend nulle le consentement matrimonial seulement si la personne dèterminèe par la qualitè n'est pas connue en personne et si une autre personne dèterminèe se substitue à elle. Le cardinal P. Gasparrri et F. Cappello en sont les reprèsentans principaux.

$\mathrm{B}$ - L'interprètation stricte considère que l'on vise plus la qualitè du partenaire que la personne elle-mème lors du contrat matrimonial. Alors l'absence de la qualitè exigèe cause la nullítè du mariage. St. Thomas, Thomas Sanchez et St. Alphonse de Liguori en sont les reprèsentants.

C - Vers 1970, on a essayè d'introduire une troisième interprètation cite ,large". Elle adettait non seulement la substitution physique de la personne, comme les deux premières interprètattions mais aussi la substitution morale de la personne quand le conjoint, en se prèsentant à son conjoit futur, avait dissimulè des qualitès qu'il ne possèdaient pas rèellement ou cachè les circonstances exactes essentiellement importantes pour la vie future du couple. Il s'agit ici en particulier des qualitès, legales et sociales. On peut trouver cette interprètation dans deux sentences de la Rote et dans deux sentences de l'officialitè de France. Elles soulignent que l'interprètation du C. 1083, 2, 1, a subit une certaine èvolution relative aux circonstances extèrieures de la qie quil ont changè apriès le Deuxième Concile du Vatican. 